\title{
Tysk politisk og kulturelt Arbejde i Nordslesvig.
}

II.

Af Redaktør Harald J. Rud.

\section{Forbindelsen sydpaa og Hjælpen sydira.}

I min Oversigt. i Sønderjydske Aarbøger 1923, I. Halvbind over tysk politisk og kulturelt Arbejde i Nordslesvig har jeg omtalt dette paa følgende Omraader: 1. Politisk Virksomhed, 2. Kirke og Skole, 3. Ungdomsarbejde, 4. Foreninger, Foredrag, Kunst og Underholdning, 5. Biblioteker, 6. Landbrug. Som et 7. og sidste Led i Rækken maa nævnes: F orbindelsen sydpa og $\mathrm{H}$ jælpen sydra. Det er et af de væsentligste Led $i$ det tyske Arbejde for Bevarelsen af Tyskheden i Nordslesvig, men Virksomhedens Udfoldelse indenfor dette Omraade har været overmaade omskiftelig i de forløbne Aar siden Genforeningen, væsentlig paa Grund af det tyske Pengevæsens totale Sammenbrud. Naar der derfor $i$ det følgende tales om Markværdier, maa hvert Tilfælde bedømmes dels efter Markens daværende Værdi og dels under Hensyn til den større Købekraft, Marken stedse har haft indenfor Tysklands Grænser, end Udlands-Kursen angiver.

I den følgende Oversigt skal kun det tyske Arbejde nævnes, der direkte har til Formaal at knytte 
Traadene over Grænsen til Nords lesvig. Derimod' vil jeg saavidt muligt ikke komme ind paa Omtale af det tyske Arbejde, der alene rettes mod Danskheden sydfor Grænsen, idet dette ikke hører ind under Emnet og forøvrigt er behandlet andetsteds.") Her skal heller ikke omtales de talrige Udtalelser, derer fremsat fra tysk Side imod vor Græense i officielle Forsamlinger eller paa private Møder. Ofte foreligger de kun i mangelfulde Referater og kan forøvrigt næppe tillægges større reel Betydning, - Ord udsprungne af Sorg, Harme eller Hævnlyst, alt efter Talerens Naturel og Forsamlingens forudfattede, ensidige Mening. Den $\mathrm{S} t$ e $\mathrm{m} n$ in $\mathrm{g}$, der fra visse $\mathrm{S}$ der søges fremkaldt, er dog ikke til at tage fejl af og skal heller ikke underkendes, men det vil i en Overs'gt over den praktiske Udfoldelse af Tyskhedsarbejdet over Grænsen være nyttigere at regne med de forelig-. gende Realiteter.

\section{Nordslesvig som Led I Udlandstyskheden}

Tyske Blade bragte i Somren 1923 som Agitation en Artikel under Overskriften:

"2 Millionen vertriebene Deutsche«.

Artiklen søger at virke ved sine Tal, idet den anfører følgende "fordrevne Tyskere«: „750,000 Auslands-Reichsdeutsche, 16,000 Kolonialdeutsche, 200,000 Auslands-Volksdeutsche aus Rusland und Ungarn, 150,000 Grenzdeutsche aus Elsass-Lothringen, 3000 Grenzdeutsche aus dem Saargebiet, 850,000 Grenzdeutsche aus Posen-Westpreussen, Soldau und Memel, 90,000 Grenzdeutsche aus Oberschlesien, 10,000 Grenzdeutsche aus der Tscheckoslowakei, 10,000

•) Jævnfør "Grænsebogen“, Slesvigsk Forlag. 
Tysk politisk og kulturelt Arbejde i Nordslesvig. 3

Grenzdeutsche a us Nordschleswig". Artiklen gør saaledes op, at hvert 30 . Menneske i Tyskland er "Flygtning ".

$\mathrm{Nu}$ indtager Nordslesvig jo en beskeden Part i denne Opgørelse, men ser man bort fra de kolossale Overdrivelser i dette Eksempel paa tysk Agitation, bliver der det tilbage, at Nordslesvig ukritisk inddrages som sideordnet Led i Agitationen imod Versailles-Freden, og at "Flygtningene" (dels bortrejste Embedsmænd, dels tyske Tilflyttere, som ikke har boet her de Par Aar, der skulde til for at faa dansk Indfødsret, og endelig de Tyske, der har solgt deres Ejendomme for Kroner og er rejst sydpaa), b r u g e s iAgitationen, der drives paa "den tabte Nordmark «. 10,000 "Flygtninge" er dog stærkt overdrevet, da de fleste lavere Embedsmænd jo blev her og gik $\mathrm{i}$ dansk Tjeneste, og af de 47 afgivne Optionserklæringer for Tyskland, blev kun 6 retsgyldige ved Overflytning til tysk Omraade!

\section{Nordslesvig I de parlamentariske Forsamlinger. - Direkte statslig Stette.}

Nordslesvig har gentagne Gange været drøftet .i de parlamentariske Forsamlinger i de forlobne Aar, iselv om det har indtaget en forholdsvis beskeden Plads.

I den ty sk e Rig s d a g var Nordslesvig paa Tale ved Behandlingen af den dansk-tyske Traktat (31. Maj 1922) umiddelbart efter Ratifikationen af Øvreslesiens Afstemning, hvor forskellige Ordførere, mest af Højrepartieme benyttede Lejligheden til ( $i$ den for Øvreslesien florklædte Sal) at udtale Haab om, ti " Uretten imod det slesvig-holstenske og tyske Folk « 
igen maatte blive gjort god. Udtalelserne mundede iøvrigt ud $i$ Kravet om en $M$ indretalstraktat, der paa dette Tidspunkt var den ny-slesvig-holstenske Agitations Maal.

I den preussiske Landdag indbragtes (April 1922) følgende Andragende med Sigte paa Nordslesvig:

"I det danske Folketing har Kultusminister A p pe 1 fremsat Forslag om Bevilling af $200,000 \mathrm{Kr}$. til danske Kulturformaal i Mellem- og Sydslesvig.

Vi stiller Andragende om, at Landdagen vedtager en Henvendelse til Statsministeriet, der gaar ud paa, at Rigsregeringen stiller Midler til Raadighed til Bevarelse af tysk Sprog og liultur i det afstaaede Nordslesvig.

Mill berg, Dr. Dryander, Bayer, Kiel, og de bvrige Medlemmer af Det tysk-nationale Folkepartis Fraktion."

Ved den danske Bevilling 1923 af 200,000 Kr. til Danskheden sydfor Grænsen, skrev "A p e $\mathrm{n} \mathrm{r}$ a $\mathrm{d}$ e $\mathrm{l}^{\prime}$ T a g e b l a t tı (3. April 1923) følgende:

"Forgaves sunrger vi: Hvad satter den tyske Regering op imod denne forholdsvis enorme Inderstattelse? Hvad gor den for Tyskerne i Udlandet? Den tyske Regering kan naturligvis ikke optage Vaddeløbet mod kronen. Men at den maa foretage noget, ligger klart for Dagen, hvis ikke Tyskheden i Gransedistriktet skal komme i den allerstorste Nod og Betryk. Det var endelig paa Tide at begynde med Gerninger. Platoniske Kaxligliedserklæringer og smukke Taler er ikke nogen Modvangt overfor 200,000 lironer.".

Af direkte Statsbevillinger til Tyskheden i Nordslesvig kendes dog ikke andre end $100 \mathrm{Mil}-$ lion Mark-Fondet fra for Afstemningen (dengang ca. $450,000 \mathrm{Kr}$.). Efter Udtalelser af $\mathrm{Dr}$. K äs t n er paa Seminariet i Rendsborg skulde 141/2 Million direkte anvendes til kulturelle Formaal i Nordslesvig. Redaktør B e c k e r bragte i 1921 et Rygte $i$ "Tondern-. 
Tysk politisk og kulturelt Arbejde i Nordslesvig. 5

sche Zeitung « om, at en Regeringskurér havde bragt 5 Millioner Mark til Tønder. Rygtet benægtedes af Pastor Schmidts Blad, og det store Beløb har i al Fald næppe kunnet spores.

I den preussiske Land dag fortes 1. og 2. Februar 1924 en længere Debat i Anledning af de danske og tyske Socialdemokraters Overenskomst om Grænsen, der blev stærkt angrebet fra alle andre Partier og kun halvvejs forsvaret af Socialdemokraternes Ordførere og de socialdemokratiske Regeringsmedlemmer, Statsminister B r a u n og Indenrigsminister Severing. Man har dog Indtryk af, at de skarpe Udtalelser nok saa meget gjaldt Agitationen imod den socialdemokratiske Regering i Preussen til det forestaaende Valg, som Arbejdet for Tyskheden i Nordslesvig.

Fra forskell'g Side er der i de forløbne Aar i Agitationens Tjeneste fremsat lignende Udtale lser i mod Grænsen, imod det danske Styre og imod Danskheden sydfor Grænsen. Det er saaledes Tilfældet fra det tysknationale Partis og det tyske Folkepartis Prov'ns-Afdelingers Side, fra højere tyske Embedsmænd, Overpræsident $K$ ür b i s, Regeringsraad Joh an nsen, ,Overborgmester Todsen, i Landdagens Hovedudvalg, $i$ det preussiske Statsraad, i Provinslanddagen, paa det slesv:g-holstenske Kobstadmøde, paa Landbrugskamrets Møder o. s. v.

I det tyske $R$ igsindenrigsministerium oprettedes der fra Nytaar 1922 et $\mathrm{s} \approx \mathrm{r} \mathbf{l}$ i $\mathrm{t} \mathrm{K}$ o n t or "til Bearbejdelse af Grænsespørgsmaal, særlig dermed i Forbindelse staaende Embedsmandsanliggender«. Kontoret ledes af den grundige Kender af nord- 
slesvigske Forhold, J o hs. Ti e d je (født i Skrydstrup) som "Ministerialrat«.

I Januar 1924 udnævntes tidligere Præst i Lintrup, Pastor $\mathrm{N}$ is se $\mathrm{n}$, til "Regierungsrat" ved Regeringen i Slesvig. Pastor Nissen tog efter Revolutionen Bopæl i Lyksborg som tysk Agitator og Tillidsmand for "Deutscher Schutzbund ". Han knyttedes for nogle Aar siden til Regeringen.

Provinsudvalget for Hertugdømme r n e, hvis Formand er Overborgmester Dr. T o ds e n, Flensborg, har hvert Aar opført og bevilget Understøttelser til forskellige Formaal og Foreninger til Fremme af det tyske Arbejde, saaledes aarligt til "Wohlfarts- und Schulverein", Bibliotekerne, Landbrugsskolen Berghof o. s. v. I Slutningen af 1923 bevilgede Udvalget 6000 Guldmark til Forarbejder til en tysk "Haandbog i det slesvigske S pørgs nı a l«, og . "Slesvig-Holstener-Udvalget« fik bevilget 300 Guldmark.

"Reichszentrale für Heimatdienst", en under Krigen dannet tysk Landsorganisation, har ogsaa beskæftiget sig med det slesvigske Spørgsmaal, hvilket fremgaar af følgende Brev, som »Hejmdal" offentliggjorde (Juli 1921):

"Reichszentrale für Heimatdienst

Berlin W. 35, den 6. 8. 1920

Potsdamer Str. 41

Fernsprecher: Kurfürst 4956, $5989,7568,7594,7510-12,9723$ $-26$

Drahtanschrift: "Heimatdienst».

Für Ihre in dankendswertester Weise verfasste $\mathrm{Zu}$ sammenstellung übor die dänische Agitation und die Sammlung dänischer Plakate, die für die Zwecke der Ruirhszentrale für Heimatdienst von grösstem Interesse 
sind, erlaube ich mir, Ihnen den herzlichsten Dank auszusprechen und Ihnen für die grosse Mühe, die Sie sich mit dieser umfassenden Arbeit gemacht haben, eine bescndere Gratifikation von 500 Mark zu überweisen.

Es ist beabsichtigt, Ihre Arbeit dem Auswärtigen Amt vorzulegen, womit ich die Hoffnung verknüpfe, dass dies Ihren Plänen vorteilhaft sein möge.

Dr. Ratje.

An Herrn $\ldots \ldots \ldots \ldots \ldots \ldots$, Flensburg.

Som et Led i Agitationen mod Grænsen og mod Danmark var ogsaa Rigspræsident Eberts Besøg i Fle ns b org 7. September 1922 ment. Dr. Todsen søgte ved denne Lejlighed at paakalde en særlig Interesse fra Rigets Side til Kampen mod Grænsen og Danskheden sydfor Grænsen; Præsidenten gik ikke ind paa Opfordringen.

I Maj 1923 afholdtes i Forbindelse med Indvielsen af Højskolen i Læk et Møde af et stort Antal t y s k e Embedsmænd fra alle Egne af Slesvig og Holsten med tyske Deltagere fra Nordslesvig.

Efter Afstemningen i 1920 sendtes følgende Skrivelse til tyske Embedsmænd i Nordslesvig:

"I Tyskhedens Interesse i Nordmarken opfordres De til saa længe som muligt at blive i Deres Stilling, ogsaa efter Afstaaelsen til Danmark. Vi udtaler Haabet om, at limbedsmændene vil oprette tyske Foreninger og stotte den tyske Agitation i Nordmarken.

Ministeren for Handel og Erhverv..

Denne Skrivelse udsendtes, saavidt vides, kun til - Skorstensfejerne, og skal kun nævnes som Kuriosum.

\section{Ungdomsarbejdet.}

Man kan ved at betragte det tyske politiske og kulturelle Arbejde ikke undgaa at lægge Mærke til, 
i hvilken Grad Arbejdet for Ungdommen optages og anvendes i Agitationens Tjeneste. Det er stærkt fremtrædende i Nordslesvig, og Gang paa Gang moder man en maalbevidst og konsekvent Bevægelse i samme Retning sydfor Grænsen. Tyskerne har, synes det, $i$ højere Grad end vi danske, haft Evne til at drage Ungdommen ind i det, de kalder wdet praktiske Grænselandsarbejde«. De har forstaaet at mobilisere Ungdommen lige fra Skolebørnenes Indsamling af Spareskillinger ("Jugendspende Nordschleswig»), til folkelige eller sportslige Ungdomsforbund, Højskolebevægelsen, og til de rent politiske Ungbondebevægelser og "Ungtyskland«-Foreninger. Der spores i denne Virksomhed blandt Ungdommen en betydelig Indsats af Energi og Offervilje, ikke mindst fra fremtrædende Pædagogers Side.

De talrige tyske Ungdomsorganisationer sydfor Grænsen deltager alle mere eller mindre direkte i Arbejdet for Tyskheden i Nordslesvig. Her skal nævnes de forreste $i$ denne Henseende:

Ungdomsforeningerne er samlede $i$ et $" N$ ordmarkbund Deutscher Jugendkorps«, der holder aarlige Fællesmoder i Form af "fædrelandske Fester" e. 1., og hvori deltager Repræsentanter for Slesvig og Holsten og særlige Repræsentanter fra Nordslesvigs tyske Ungdomsforbund. Om Fællesorganisationens Formaal hedder det $i$ en Artikel i "Flensburger Nachrichten«:

»Nordmarkforbundet knytter alle de mange fædrelandske Ungdomsforeninger i Nordmarken, der staar paa Ungtysklandforbundets Grund, sammen til fælles Handlen. Det vil i første Linje yde praktisk Grænselands- 
Tysk politisk og kulturelt Arbejde i Nordslesvig. 9

a r bejde med sine Medlemmer. Politisk Virksomhed er strengt udelukket af dets Rammer."

Forbundet har ved et af sine Møder i Flensbory fastslaaet, at det "bevidst vilstillesig i det tyske Kulturarbejdes Tjeneste nordog s yd for Grænsen«. Til dette særlige Formaal nedsattes et særligt "NordgrænselandsUd v a $l g$ «, bestaaende af Pastor Tonnese n, Rendsborg (før Hellevad), Landraad S te l zer, Rendsborg, Pastor Kä h l e r, Flensborg, Skoleraad G r ond a h l, Flensborg (før Aabenraa) samt nogle unge.

Forbundet har foranstaltet "Nordmarkstævner" i Flensborg i Forbindelse med Sportsfester og Ung. domsmøder, Folkemøder, "Grænseungdomsstævner $"$, (1924 i Slesvig) Sommermode (1923 i Hohenwestedt) med Hjemstavnsaftener og Drøftelser af nordslesvigske Forhold, indledet af Pastor S ch mid t, Ungdomsleder Fr. Christensen, Aabenraa, og forskellige Vandrelærere fra Nordslesvig. Endvidere afholder Ungdomsforeningerne en Sommerfest paa Askebjerg ved Hütten i Lighed med tidligere Knivsbjergfester, og ligesaa paa Skærsbjerget, hvor der foruden Sport og Folkefest ogsaa opfores nationale Skuespil. Bismarck-Statuen fra Knivsbjerg er som bekendt ført til Askebjerget.

Ved Indvielsen af Folkehøjskolen i L $æ$ k, 29. Apri\} 1923, holdtes el større Ungdomsstævne med Deltagere fra begge Sider af Grænsen.

Endnu et "Gr æ n s e u d v a l g“, bestaaende af Overlærer Tränckner, Slesvig, Højskoleforstander Kr u s e, Læk (før ì Haderslev), Skoleraad G rønd a $\mathrm{h}$ l, Flensborg, W. J e n s e n, Skoleraad Ki e s b y 
og $\mathrm{S}$ c h $\mathrm{r}$ i e w e $\mathbf{r}^{\star}$ ), indbod desuden den tyske Grænseungdom til et særligt "Førerkursu su:

"Vi vil meddele, hvorledes der arbejdes i Grænsedistriktet, og alle i Fællesskab drofte, hvilke Opgaver fremfor alt Ungdommen og dens Forbund har at opfylde i Grænsekampen."

Lederen af disse Ungdomskursus, Overlærer Trä n ck n e r betegner i en Artikel i de tyske Græn- . seblade (Oktober 1922) disse som et "Forarbejde for Folkehøjskolen i Læk". Der holdtes i Vinteren 19221923 Kursus $i$ tre Landsbyer nær ved Grænsen, og Deltagerne var unge Mennesker fra 18-25 Aar af begge Køn. Der var indtil 30 Deltagere af hvert Kon, men i Fremtiden, skriver Hr. T., bør 12-15 være det højeste Antal i en Gruppe. Der undervistes først og fremmest i slesvig-holstensk Historie; Emnerne var saaledes: Urtiden, Vandringstiden, Kristendommen, Danevirke, Samfundslære og Statsvidenskab, Pengevæsen (med særligt Henblik paa Grænsedistriktet) Penge som Middel for den enkelte og som politisk Middel for Staten, Hjemstavnsdigtning (Theodor Storm) o. s. v.

Et Førerkursus strækker sig over 14 Dage og er beregnet for Folk i Alderen 20-30 Aar.

Ved et Møde (December 1923) i Egernførde vedtoges det "i endnu stærkere Grad end hidtil " at tage fat paa det praktiske Grænselandsarbejde, neml'g ved at danne et A r bejdsfællesskab» med Landbund, Jungdeutschlandbund, og Krigerforbundene.

I Forbindelse med Ungdomsforbundene, hvis Virksomhed rækker direkte til Nordslesvig, maa næv-

*) Dr. Schriewer er Leder af Centralen for de tyske G:ænsebiblioteker. 
nes Organisationen af "Jungfrauenverein". Desuden de i Sydslesvig og Holsten i de senere Aar opstaaede "Jungbauernschaften", der er sammensluttede i "Verband schleswig-holsteinischer Jungbauernschaften", (Formand Andreas K 1 i nker, Sekretær E. Ruge) Rytterforeningerne, "Jungdeutscher Orden", osv. Disse Foreningers Virksomhed strækker sig dog ikke direkte til Nordslesvig.

Foruden de lokale Ungdomsorganisationer findes et wDeutscher Reichsausschuss für Jugend-Grenzlandarbeit."

\section{Folkehøjskoler - Universitetskunsus.}

"Folkehøjskolens Aand har vundet 1. Zone for Danmark, og Danmark vover med den Fremstodet mod Syd, og vi har ingen kulturel-aandelig Kraft af samme Vægt at sætte imod. Vægten af Angrebet fra Norden og Tidernes Alvor fordrer, at der ogsaa fra vor Side skrides til Handling", - skrev "Rendsburger Tageblatt«, ("Schleswig-Holsteinische Landeszeitung«) ved Aabningen af den første tyske Folkehøjskole efter Genforeningen ved Rendsborg. Foruden de gamle Hjemstavns-Højskoler i Ma arkær-Østersk ov i Angel og i L unden i Ditmarsken, har Tyskerne i de sidste Aar rejst nye i et Bælte langs Grænsen. De har saaledes i Øjeblikket, foruden de gamle, Skolerne i Rendsborg, Læk og Harreslev, der alle modtager Støtte af Wohlfahrts- und Schulvere:n til Elever fra Nordslesvig.

Højskolen i Maarkær-Østerskov er den ældste i Provinsen. Den holder i Vinteren 1923-24 sit 28. Kursus, men har kun haft faa Elever fra Nordslesvig. Det samme er Tilfældet med den anden Hjemstavns-Skole i L u n d en. 
De egentlige Grænseskoler, som er rejst direkte med Nationalitetskampen for $\emptyset \mathrm{je}$, er Rendsborg, Lak og Berghof i Harreslev.

Højskolen i Rends borg blev aabnet sidst $i$ Oktober 1921 i den store Ejendom "Kanalblick« ved Kanalen, der blev omdannet og udsmykket til Grænseskole. Dens Formaal blev i et Opraab betegnet $i$ følgende Ord: Tysk opdragelse paa Hjemstavnskuturens Grund. Skolens Forstander er tidligere Rektor A. Henningsen, (født i Haderslev, senere ansat i Broager). Lærerkræfterne bestaar iøvrigt af Pastor Johs. T on nes e n, Rendsborg, (før i Hellevad), Kredsskoleraad S chach t, Rendsborg, (for i Aabenraa), Landraad S t e l t z e r, Rendsborg, og Lærer $\mathrm{H}$ o l s t, Rendsborg. Skolen har Plads til 30 Elever og begyndte 1. November 1921 sit forste Kursus med fuldt Hus.

Rendsborg-Skolen har i 1922 optaget en ny Form for slesvig-holstensk Kulturarbejde, nemlig V a ndrekursus. Naar et Antal Personer (12-40) samles et Sted, afholdes et to Dages Kursus, hvortil Højskolen opstiller -en Arbejdsplan, med Foredrag om forskellige Emner som "Folkefællesskab og Erhvervsskildringer", "Nordmarkkampen og Kulturpol"tikken", "Opdragelses- og Ungdomsproblemer", „Grænse- og Udlandstyskhed", „Forbindelsen mellem det okonomiske Liv og Kulturen « osv. Skolen stillerForedragsholdere til Disposition.

Højskolen i $\mathrm{L} æ \mathrm{k}$ byggedes i 1921-22 og var saavidt færdig, at den kunde begynde sin E f t e r s k o le i Sommeren 1922. Efterskolen er beregnet for unge Nordslesvigere, som ("ved Tyskhedens Væsen«) skal forberedes til Hjemstavns-Folkehøjso- 
1 e n s Undervisning, der er den anden Side af dens Virksomhed. I Efterskolen undervises ogsaa efter $\emptyset$ nske i dansk Sprog. Til Forstander er antaget Seminarielærer K r u s e fra Segeberg, (tidligere Haderslev). Skolens officielle Indvielse fandt Sted 29. April 1923 i Forbindelse med en »tysk GrænseungdomsDag« og "Førerkursus«. Skolen modtager Støtte fra Wohlfahrts- und Schulverein. I Sommeren 1923 bevilgede (foruden Bidrag fra anden officiel Side, som alle Højskolerne faar), Provinsial-Udvalget en Sum paa 5 Millioner Mark og "Uldsalgs-Selskabet« i Grünberg i Slesien sendte 1 Million. I 1921 bevilgede Oldenborg Kreds 5000 Mark og Ejdersted Kreds 4000 Marḱ til Grænsehøjskolerne. Disse Bevillinger fortsættes sandsynligvis. I Foraaret 1923 bevilgede den ny-oprettede Girocentral i Flensborg 20 Millioner Mark til kulturelle Formaal osv.

I de forskellige Skolers Afslutningsfester i September 1923 deltog Ministerialdirektør Kästner, der overgav Skolen i Læk 100 Millioner Mark til et Fond for trængende Elever. Ved en Indsamling forhøjedes Summen til 800 Millioner, der straks blev "værdifast《 anlagt som et "Kästner-Fond".

Som en Frugt af "Wohlfahrts- und Schulverein«s Arbejde maa ogsaa $» D$ eutsche Schule Berg$h$ o $f$ " betragtes. Den er indrettet paa en af Flensborg Kreds købt Ejendom paa Harreslev Mark. Skolen er h̆alvvejs Høj- og Landbrugsskole. Den aabnedes 1. Oktober' 1921; og der er Plads til ca. 20 Elever (fortrinsvis for Nordslesvigere). Af Undervisningsplanen fremgaar det, at der $i$ et Vinterkursus gives 120 Timer i Tysk og Historie, 60 Timer i Samfundslære, 60 i Regning, 70 i Naturkundskab og 70 i praktiske Øvel- 
ser. Skolen har i disse Aar jævnligt holdt "tyske Aftener", og "wess Geistes Kind" den er, viste sig, da den i August 1923 blev 1 uk k et af sit Kuratorium, fordi nogle af. Eleverne nægtede at hejse Rigsflaget paa Forfatningsdagen. Af Pressekommentarerne til den opsigtsvækkende Begivenhed fremgik det, at Skolen blev drevet højst middelmaadigt som Landbrugsskole, idet alle Eleverne trykkede sig ved at arbejde,") men saa meget stærkere i nationalistisk og republikansk-fjendtlig Aand. Skolens Bestyrer, Hr. L orenzen havde gjort fælles Sag med Eleverne, medens Formanden for Kuratoriet og den praktiske Leder, Hr. Friedri ch s e n fra Hatlund Mose, nedlagde sit Hverv, og Kredsdagens tilsynsførende, Økonomiraad J e n sen, Oksager, fralagde sig under en Drøftelse i Kredsdagen ethvert Ansvar for, hvad der kunde ske paa Skolen. Han oplyste iøvrigt her, at Eleverne selv i Høstens travle Tid arbejdede med. Uret i Haanden og tilsidst strejkede, saa man maatte antage 12 arbejdsløse til' en Løn af 54 Millioner daglig! (Høsten 1923). Der nedsattes et Undersøgelsesudvalg. Paa et senere Møde (September 1923) forkastede Kredsdagen dog et Forslag om Bortforpagtning af Skolen; den skal føres videre under egen Forvaltning, men med ny Ledelse og skarpere Tilsyn, og ventes aabnet i Foraaret 1924. "B e r g h of-Foreningen«, der bestaar af Forældre og Elever, har dog udsendt en offentlig Protest mod Genaabningen, inden der er foranstaltet ny Undersøgelse. Foreningen mener nemlig, at Eleverne er bortvist med Urette!

Af andet Skolearbejde skal endnu nævnes en paa Flensborgs Magistrats Foranledning oprettet $H$ a $n$ -

*) »Flensburger Volkszeitung«. 
Tysk politisk og kulturelt Arbejde i Nordslesvig. 15

d e Is s k o l e, særlig beregnet for unge fra Nordslesvig, (April 1921), en Skole for unge Kvinder: "Marthabund" i Slesvig, ("som et Bolværk til Værn for Tyskheden i Nordgrænsëlandét«), Aarssitævner af Foreninger af tidligere Elever fra Højskolen i Tinglev og fra Augustenborg Kvindeseminarium osv.

Endvidere er det paalagt de højere Skoler og en af Preussens 50 saakaldte "Aufbauschulen", der er lagt $\mathbf{i}$ Nibøl, at varetage særlige Grænseopgaver.

Paa samme Maade har

\section{Christian Albrecht-Universitetet 1 Kiel}

sine "særlige Opgaver" i det tyske Grænsearbejde. Det rogter dem dels direkte ved at arrangere talrige "Nordmark«-Foredrag, Universitetsuger i Grænsebyerne og i Landsdelens større Byer (med Gæster fra Nordslesvig), Nordmarkuger i »Hochschulring deutscher Art«, hvorigennem Studenter fra hele Landet interesseres osv., og dels igennem "Det slesvig. holstenske Universitetsselskab« (For. mand fra 1918-23: Generalsuperintendent Dr. M o r dh o r s t, Kiel, derefter fhv. Landdagsmand Dr. S c h i ff e r e r, Charlottenhof).

Af Rigsregeringens 100 Millioner Mark-Fond fra 1920 overvistes ${ }^{3} / 4$ Million til dette Selskab under Hervisning til, at

"Universitetet har trofast opfyldt sin Pligt som Ud. dannelsessted for aandelige Førere i Slesvig-Holsten og i Nødstider som Forkæmper mod Danskheden. Igennem det skal ogsaa de kommende Vogtere af den tyske Nordmark uddannes." ")

Der er i de senere Aar stillet meget betydelige Midler til Raadighed for Universitetet til "Nordmark-

*) Sonder-Satzungen für Die schleswig-holsteinische Universitäts-Gesellschaft. 
Formaal«, navnlig fra private i Ind- og Udland (saaledes 30,000 Guldmark fra Gøteborg) og ved Indsamlinger (1921 i Flensborg 100,000 Mark).

Universitetet har udnævnt Overborgmester Dr. Todse n, Flensborg, til Aresmedlem ("Roland der Nordmark ("), og Folketingsmand Pastor S ch mid t til AEresdoktor ved det teologiske Fakultet.

\section{Indsamlingex I Skolerne.}

For at skaffe Midler til de tyske Vandre- og Familieskoler i Nordslesvig, (hvor der i Øjeblikket virker en halv Snes Vandrelærere) er der iværksat en saakaldt "Jugendspende Nordschleswig" i alle Skoler i Slesvig og Holsten. En af Ideens Forkæmpere, Lærer Karl B r ü $g$ g e, Flensborg, har paa en "Nordmarksaften« i Flensborgs Lærerforening (Oktober 1922) oplyst, at der en Gang om Maaneden foretages Indsamling af (helst faste) Bidrag fra Børnene i en Række Skoler i Slesvig og Holsten. I Labet af Vinteren tager Organisationen fast Form, og - i. 1922 indsamles et meget betydeligt Beløb (efter de sparsomme Opgivelser, der haves, ca. 200,000 Mark i Altonas Skoler). I 1923 agiterer en Studienrat Tre u t, Bromberg, fra "Foreningen for Tyskheden i Udlandet“ for Jugendspende paa en Række Møder i de fem største Byer. Det meddeles (April 1923), at F or e n i ng e n "Jugendspende Nordschleswig" omfatter over 200 Skolegrupper. Fra Byerne var der da indsamlet (delvis ogsaa ved Husindsamling):

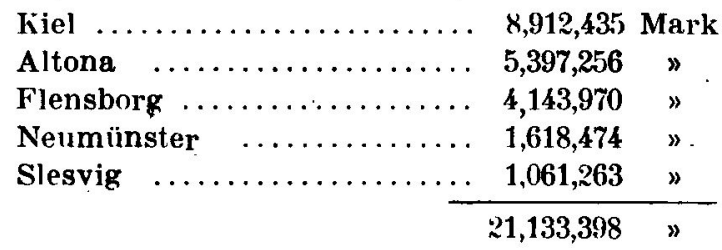


En Del af Beløbet blev i Foraaret 1923 anvendt $\mathbf{i}$ 2. Zone, da Hovedudvalget for "Jugendspende", (Lærer Brügge) ved Juleindsamlingen kunde meddele, at

"Samtlige Privat- og Vandreskoler i det afstaaede Omraade kunde udrustes efter Behov med Skoleutensilier, Lare- og Undervisningsmidler af enhver Art paa mønsterværdig Maade.«

Desuden havde Foreningen sydfor Grænsen kunnet oprette 14 udmærkede Skolebiblioteker.

\section{Foreninger, der yder stotte.}

Et saa omfattende Arbejde som det, Tyskerne udfører paa alle Omraader til Hjælp og Støtte for deres Landsmænd i Nordslesvig, kan kun udføres ved virksom Hjælp fra godt organiserede Fore $\mathrm{n}$ in g e r. Og Organisationens Kunst forstaar vore Modstandere sig paa! Foruden forskellige landsomfattende Organisationer som den gamle "Verein für das Deutschtum im Auslande", "Deutscher Schutzund Trutzbund « o. fl., er der en Række Sammenslutninger, hvis Formaal er koncentreret ved den danske Grænse.

Den ældste og største tyske Grænseorganisation er "Verein fürdas Deutschtum im AusI a nd e", (stiftet 1881, Formand: fhv. Gesandt, Ekscellence v. D i r s e n, Berlin). Den har igennem Aarene indsamlet meget betydelige Pengemidler, og efter Krigen, under de nye Grænseforhold har den optaget Arbejdet med endnu større Kraft. Paa Foreningens Aarsmøde i Kulmbach 1922, hvori forøvrigt ogsaa Pastor Schmidt deltog, oplyste Næstformanden, fhv. Kontreadmiral S e b o h m, Berlin, at Medlemstallet fra 1919-21 var 6 Gange fordoblet (til 360,000). I 1922-23 steg Medlemstallet, (efter Beretningen paa 
Aarsmødet i Hamborg 1923), til 1 Million, fordelt i 3000 lokale Afdelinger. I Maj 1923 holdt Foreningens Sk o l e gru p per Aarsmøde i Hamborg. Disse omfattede da 1000 Enkeltorganisationer med 600,000 Medlemmer.

I 1924 holdes Aarsmede i Graz (Steiermark).

I 1921 har Foreningen indsamlet 3 Millioner Mark.

- til "udlandstyske Skoler, Biblioteker og andre Kulturindretninger". Deraf har Ungdoms- og Skolegrupperne tilvejebragt 1 Million. Pastor Schmidts Blad "Neue Tondernsche Zeitung " oplyser, at en betydelig Del deraf er anvendt i Nordslesvig. Om Indsamlingerne i de sidste Aar foreligger der ikke offentlige Beretninger.

En tilsvarende landsomfattende Organisation er "Deutscher Schutz- und Trutzbund für Grenz-, Kolonial- und Auslandsdeuts c h e«, (Formand: Stadtrat Gilg, tidligere Kolmár), Organisationen blev stiftet ved et Mode i Rigsdagsbygningen i Berlin 1920. Den har holdt store Aarsstævner i Klagenfurt (1921), Allenstein (1922) ogFlensborg (1923) med Udflugt til Sild igennem "den danske Korridor " over Tønder og Højer. I Møderne deltog Tyskere fra 20 europæiske Lande.

Begyndelsen til "Schutzbund" blev gjort i Maj 1919, da der blev oprettet en Centralforening for følgende 6 store Organisationer: "Verein für daq Deutschtum im Auslande", "Vereinigung Deutschevangelisch im Auslande», "Der Reichsverband der katholischen Auslandsdeutschen", "Die deutsche Kolonialgesellschaft«, "Die Vereinigung für Siedelung und Wanderung", og "Der Bund der Auslandsdeutschen«. Efter Aarsberetningerne omfatter Organisa- 
tionen nu 100 forskellige Forbund med et samlet Medlemstal af ca. $20 \mathrm{M}$ illioner ! Det er saaledes intet Under, at »Schutzbund«s "geschäftsführender Vorsitzender" A l bert W a cker, Berlin, i Anledning af Allenstein-Stævnet karakteriserede Organisationen med følgende Ord:

"sDeutscher Schutzbbund" er ikke nogen Forening, men den er det tyske Folkefællesskabs Idé, Livsfællesskabet af alle dem, der føler tysk."

(i »Hamburger Fremdenblatt«.)

I Afstemningstiden for de forskellige Omraader var Forbundet meget virksomt. Det samler hvert Aar betydelige Pengemidler ind. Paa Aarsmoderne, der fremtidig holdes sammen med "Verein für das Deutschtum im Auslande«, deltager Tyskere fra Nordslesvig, saaledes Pastor Schmidt og fhv. Rektor Ko opmann.

Mere koncentreret om tysk Arbejde syd- og nordfor Danmarks Grænse staar de to vigtigste hjemlige Organisationer " $S \mathrm{chleswig}-\mathrm{Hols}$ teiner Bund" og "Wohlfahrts- und Schulverein f ür Nordschleswig«, der begge er opstaaet efter Revolutionen. De to Organisationers Virksomhed har igennem flere Aar været omtrent ligeløbende, hvad Forholdet til Nordslesvig angaar, - "S.-H. B." har været mere politisk præget og $» W$. und S.« mere kulturelt.

"Schleswig-Holsteiner Bund", (Formand: Dr. Todsen, Flensborg, i Bestyrelsen bl. a. Justitsraad Dr. Löh m a n n, Flensborg, Landdagsmedlem Fru Jane Voigt, Flensborg, Gaardejer I v e r s e n, Munkbrarup, Landdagsmand M i 1 l b e r g, Quarnbek, samt fra Nordslesvig Gaardejer S chmidt, Øster Terp, der 1923 afløste Redaktør 
$\mathrm{B} ø \mathrm{~d}$ e w a d t, Tønder) omfattede allerede 19218 Forbund i Slesvig og 13 i Holsten med ialt 77 lokale Foreninger, (efter Oplysninger paa Aarsmødet i Flensborg i August 1921). Ved Aarsmødet i Kiel Juni 1922 oplystes det, at Antallet var steget til 130. Samme Aar sluttedes "Bund der heimattreuen Oberschlesier" og "der Ost- und Westpreussen", sammen med »Schleswig-Holsteiner Bund«. Der findes nu ud over Slesvig og Holsten en Række lokale Afdelinger, ialt 40, deriblandt i Hamborg og Berlin, hvor et ivrigt Medlem, Hr. Carl S c h malf e ld t i et Par Aar har udgivet et meget aggressivtTidsskrift $" \mathrm{D}$ i e $\mathrm{K}$ ö $\mathrm{n}$ ig sa u«. I dette Blad kritiserede Udgiveren og Overlandsretsraad Mathiesen, Kiel, i 1922-23 ubarmhjertigt Ledelsen af Forbundet, fordi det ikke var skarpt nok i sine Krav, men holdt paa "Selvbestemmelsesretten" (ग: Tiedjelinjen) i Stedet for "up ewig ungedeelt«. Ligesaa kritiseredes Medlemsbladet "Der Schleswig-Holsteiner"s Redaktør, Overlærer T rä n ck n e r, fordi det var for vegt overfor »dansk Overmod«. Aktionen fremkaldte direkte Forslag fra Kieler-Lokalforeningen paa Aarsmødet i Kiel 1922, om "mere energisk og maalbevidst politisk Ledelse af Forbundet". Som Følge af disse Krav nedlagde et fremtrædende Medlem af Hovedbestyrelsen, Overlæ: rer Dr. Karl A 1 n o r, Flensborg, sit Mandat, men iøvrigt red Ledelsen den Schmalfeldt'ske Storm af, og »Die Königsau“ gik ind i September 1923.

Forbundet har en betydelig Gruppe $" D$ e uts c hI a n d-W e s t«, der er stiftet af Oberstaatsanwalt Dr. H a nse n, Bochum. Hr. H., der er fra Haderslev, er senere forflyttet som Generalstaatsanwalt til Kiel. Dr. Hansen konstaterede i Afstemningstiden, at der i 
Rhinlandets Byer var 750 Indbyggere, der var født $i$ 1. Zone, og 800 , der var født i 2. Zone, og paa Basis deraf organiserede han "Deutschland-West" med 18 lokale Foreninger. Gruppen har holdt store Stævner i Bochum og Elberfeld. Som en særlig Opgave har "Deutschland-West" paataget sig Understøttelsen af t yske Ung domsh jem i Nordslesvig.

"Schleswig-Holsteiner-Forbundet«s Virksomhed. har dog ikke været dets Stiftere og Ledere tilstrækkeligt. Det var - som ovennævnte Generalstaatsanwalt Hansen udtrykte sig paa et Mode i Kielerforeningen i 1923 - »ikke blevet det, man havde ventet: en Stemme og en Udtryksvilje for det slesvig-holstenske Folk«. Derfor skred man til endnu en S a mmens lutn ing af meget betydeligt Omfang, og den 28. September 1923 offentliggjordes følgende Opraab i tyske Grænseaviser:

\section{Slesvig-Holstenere!}

I det Øjeblik, hvor indre Sammenhold mere end nogen Sinde er fædrelandsk Pligt, bliver der paa uforsvarlig Maade udbredt og troet Rygter i Landet, der ikke blot fremkalder Forvirring, men ogsaa skal tjene landsforræderske Formaal.

De undertegnede Forbund, der har sluttet sig sammen til fælles Arbejde for Hjemstavn og Fædreland, erklærer hertil:

1) I Mindet om sine Forfædre er Slesvig-Holsten ogsaa under den dybeste tyske Nød uadskilleligt forbundet med Rige og Stat.

2) Ethvert Forsøg paa at afstaa yderligere slesvigholstensk Jord til Danmark vil i hele Slesvig-Holsten støde paa den stærkeste Modstand.

3) Til Opretholdelse af den offentlige Sikkerhed og Orden maa enhver Slesvig-Holstener under alle Forhold stille sig paa Forfatningens Grund bag Regeringen og 
støtte Rigs- og Landsmyndighederne i Opfyldelsen af deres Opgaver.

Flensborg, 26. September 1923.

Slesvig-Holstener-Forbundet, Rigslands-Forbundet for Slesvig-Holsten, Slesvig-Holstensk Bondeforening, Det slesvig-holstenske Landsforbund indenfor det nordvesttyske Haandværkerforbund.

Der var her fuldbyrdet en Sammenslutning imellem det grænsepolitiske "Schleswig-Holsteiner Bund" og en Række økonomiske Organisationer. Der var tilvejebragt det, man betegnede som Øjeblikkets Krav: "en ensartet Sammenfatning af de økonomiske Kræfter i Grænse- og Hjemstavnspolitikken«.

Kort Tid efter (20. Oktober 1923) holdt "SchleswigHolsteiner Bund« sit 4, Aarsmøde paa Højskolen ved Rendsborg. Der deltog Repræsentanter fra de 120 Afdelinger i Landsdelen. Det vedtoges at udgive Medlemsbladet "Der Schleswig-Holsteiner" hver 14. Dag sammen med de to store Landbrugsforeningers Blade i et Oplag af 40,000 . Bladets Redaktion overtoges af Pastor Tonnesen og Forstander A. Henningsen, Rendsborg. Stævnet sluttede med Vedtagelsen af en Resolution, der synes at vise Frygt for Uroligheder, baade fra dansk Side og af indre social Art.

Korrespondenzbureau Nordschleswig har udsendt den korte officielle Beretning om Mødet. Alene af den fremgaar det, at vi i "Schleswig-Holsteiner Bund" har det politiske Hovedsæde i Agitationen fra tysk Side, Hovedarrangøren af de store altysk-prægede Stævner og Fester den 14. Marts (Afstemningsdagen for 2. Zone), den 24. Marts (Aarsdagen for den slesvigholstenske Rejsn'ng) osv.

Om "Wohlfahrts- und schulvereinus Formaal udtalte dens Formand, Landraad W a ll- 
Tysk politisk og kulturelt Arbejde i Nordslesvig. 23

roth, Flensborg, sig ved et af Foreningens Bibliotekskursus i Flensborg i 1922:

"Velfærds- og Skoleforeningen er en fri, upolitisk Organisation, der er baaret af alle Befolkningslag, og som aet bl. a. paahviler at forankre Tyskheden og den tyske Kultur her i Grænseomraadet. Det gælder om at bevare vore Fædres Land tysk, det Land, hvis kernetyske Karakter Afstemningen den 14. Marts 1920 paany har bekræftet.»

("Flensburger Nachrichten".)

Om Foreningens Virksomhed hedder det i Beretn'ngen paa Aarsmødet i Flensborg for 1921, at der var »den største Rørighed paa alle Kulturplejens Omraader i Grænsedistriktet paa begge Sider af Sønderaaen (Skelbækken). I det forløbne Aar er det faste Grundlag lagt til en planmæssig Udbygning af Bibli ot eksvæsenet. Forsyningen af Nordslesvig med Bøger har nu som før Lokalforeningen i Kiel (der tæller 900 Medlemmer), taget sig af med Iver og godt Resultat. For Folkehøjskolebevæg els en har Foreningens korte Kursus haft stor Betydning

I 1921 er der af Foreningens indsamlede Midler ydet St u diehjælp til Nordslesvigere paa tyske Undervisningsanstalter til et Beløb af 110,000 Mark. Af de 110 understøttede $\mathrm{i}$ dette Aar var 20 fra Haderslev Amt, 29 fra Aabenraa Amt, 28 fra Sønderborg, 31 fra Tønder Amt og 2 fra det afstaaede Omraade af Flensborg Amt. Af 90 unge Mænd besøgte 43 Landbrugsskoler, 18 industrielle, 4 kunstindustrielle, 8 Handels- og 11 Folkehøjskoler, 6 Universitet og Seminarium. De 20 unge Piger fordeler sig med 16 paa Folkehøjskoler, 2 paa industrielle og 2 paa Fagskoler. I alt er der siden Foreningens Oprettelse i Sommeren 1920 (og indtil Udgangen af 1921) ydet ca. 200,000 Mark til 183 Ansogere. Af Fripladser og Stipendier er der 1920 skaffet 16., i 192134 og i 192241 til Nordslesvigere. 
Efter en Opgørelse af Studienrat $L$ ü $t$ z e n $k$ irche n, Kiel, (tidl. Haderslev) disponerede "Wohlfahrts- und Schulverein" allerede i 1921 over følgende Fripladser og Stipendier for tyske Nordslesvigere:

Flensborg: Landbrugs-Vinterskolen 3 Pladse ${ }^{*}$ a 1500 Mark, 1 Plads efter eget Ønske, 1500 Mark, højere Læreanstalter 3 Fripladser, Mittelschule 3 Fripladser, Kunstindustriskolen 3 Fripladser. S l e s vi g: Fripladser i Byens Skoler. Egernførde: Kreds-Vinterskolen 1 Friplads, 1 efter eget Ønske 1500 Mark. M a r n e: LandbrugsVinterskolen 5 Pladser a 1500 Mark, 1 a 750 Mark, 1 Stipendium 100 Mark. A I t o n a: Gewerbeschule 3 Fripladser. Ho h e n w e s t e d t: Landbrugsskolen 3 Pladser tilsammen 1500 Mark. H a de mars ch en: Husholdningsskolen 3 Stipendier tilsammen 1000 Mark. O lde s l o e: LandbrugsVinterskolen 2 a 1000 Mark. R a t z e b u r g: Gymnasium 1 Friplads, Vinterskole 1 Friplads, 2 Stipendier 600 Mark. It z e h o e: Landbrugs-Vinterskolen 1 Friplads, Augusta Viktoria-Lyceum 3 Fripladser. Pre et $z$ : Landbrugs-Vinterskolen 3 Stipendier a 300 Mark. S e ge berg: Landbrugsskolen 1 Friplads. Ka l te $\mathrm{n}$ i r chen: Landbrugsskolen 1 Friplads. Kiel: Musikkonservatoriet 3 halve Fripladser, 2 hele, Klaverakademi 1 halv Friplads, Landbrugskamrets Husholdningsskole halve Fripladser, Handelsskole 2 Fripladser, Mittelschule 2 Fripladser, Lyceum 2 Fripladser, Landbrugsskolen 1 Friplads. Wil hel ms haven: Højere Pigeskole 1 Friplads. L y bæk: Byens Skoler Fripladser, Bygningsskolen 2 Fripladser. B a r men: Fripladser paa Haandværker- og Kunstindustriskolen, højere Væveskole, Handelsskole. Dresden: Fripladser i Byens Skoler. Desuden disponerer Foreningen over 16 Fripladser og Stipendier ved Statsskoler.

Som det vil ses heraf, faar "Wohlfahrts- und Schulverein« megen Støtte fra offentlig Side. Det var til denne Forening Landraad $S$ i e mo $n$ i Aabenraa egenmægtigt overviste en meget stor Sum af Aabenraa Kreds' Midler fra "Kreisgeschäftsstelle«s Virksomhed i Krigsaarene. Foreningen faar stadige Tilskud fra en Række Amter og Byer, bl. a. Flensborg 
Tysk politisk og kulturelt Arbejde i Nordslesvig. 25

(1921 3000 Guldmark 1923300 Guldmark), og Foreningens Forvaltningsraad har i Februar 1924 afholdt Møde i Overpræsidiet i Kiel.

En særlig nordslesvigsk farvet, mere selskabelig Karakter har de talrige "Vereine heimattreuer Nordschleswigeru. Snart hedder de "Landsmannsschaft der Nordschleswiger", snart „Verein deutscher Nordschleswiger" eller "vertriebener Nordschleswiger" osv. De er alle oprettede i Aarene efter Genforeningen og begyndte flere Steder som i Flensborg og Kiel som politiske Agitations- og Understøttelsescentraler, der endog havde Forbindelse med et saakaldt "Flü chtlingsstelle Nordschleswigu, der af lidt mere end menneskekærlige Hensyn tog sig af en Del af de uheldige Eksistenser, som det danske Statspoliti nægtede Opholdstilladelse paa Grund af Lovovertrædelser. Senere organiseredes "Nordslesviger-Foreninger" i alle Provinsens Byer med Hovedsæde i K i e l. Som Medlemmer optages dels Folk, der var født i Nordslesvig, og dels Folk, der har boet her i kortere eller længere Tid, saaledes alle Embedsmænd, der overhovedet har haft Ansættelse her. Med Tiden er dog vistnok overalt Rammerne udvidede til at omfatte alle, der vil med til den udfordrende Agitation - og omfattende Selskabelighed, der oves i Foreningerne.

Vi genfinder indenfor denne Agitationsforenings Ramme en Række Navne paa gamle bekendte fra før i Tiden: I Kiel Foreningernes Formand, Bankdirektør Erich s en, (tidl. Skærbæk), Pastor B e r the ls e n (tidl. Snogbæk), som storpatriotisk Taler, fhv. Amtsforstander Rafalski (tidl. Rødding), i Flensborg: Foreningernes Næstformand, Advokat v. 
Hiel m crone; (tidl. Aabenraa), Pastor $\mathrm{N}$ is sen, ( $t$ dl. Lintrup), Kredsskoleraad Gr ö n d a h l, (tidl. Aabenraa), i Rendsborg: Seminarieforstander In gwersen (født i Aabenraa), i Lybæk: Herredsfoged K l i n k e r, (tidl. Nordborg) o. s. fr.

Der er, som nævnt, aprettet Nordslesviger-Foreninger i næsten alle Byer i Slesvig-Holsten og i. nogle Landsbyer $i$ det nordlige Sydslesvig. De dyrker alle Selskabeligheden i stor Stil, Dilettantkomedier osv. Flere Enkeltforen'nger har optaget "F a dd e r s k a e t« for nordslesvigske Byer og Landsbyer, foretager særlige Indsamlinger for at holde unge $\mathrm{Ty}$ skere paa Skoler i Tyskland. Der fremvises Lysbilleder fra Nordslesvig og skænkes Billeder t"l Skolerne i Sydslesvig og Holsten. Der indsamles Pas til Visering, arrangeres Sommerrejser til Nordslesv'g, og holdes Fester med indbudte tyske Foreninger nordfor Grænsen.

Forbundet af Nordslesviger-Foreninger er indmeldt i »Schutzbund «.

Endnu kan nævnes en lang Række Foreninger, der alle mer eller mindre deltager i tysk Grænselandsarbejde, men har mindre Betydning, sealwies Foreningen "H e i mattre u" i Flensborg, "N ordfriesischer Verein für Heimatkunde und He "matliebe" i Nibøl, "Vaterländischer Frauenverein« (Fru Overborgmester Todsen), Plattyske Forening "De Eekboomu, "Niedersächsischer Sängerbund", "Verband schleswig-holsteinischer Jungba uerschaften", "Jungdeutscher Orden«, "Vereindeutscher Nordschleswiger in Hamburg«, "Klub Sonderburg« i 
Tysk politisk og kulturelt Arbejde i Nordslesvig. 27

Hamborg, samt forskellige Teaterforeninger, Kunstselskaber osv.

Som Læserne vil se af ovenstaaende Redegørelse, er det tyske Arbejde, der knytter Traadene mellem Tyskheden i Nordslesvig og Tyskland, stærkt organisatorisk udbygget, og for en stor Del er det ikke blot Former men ogsaa Liv. Ofte gør Arbejdet Indtryk af at være baaret af stærk Fædrelandsfølelse, undertiden af en fanatisk slesvig-holstensk Trang til at hævne Nederlaget overfor Ententen, - hvortil den tyske Agitation ogsaa regner Afstemningsnederlaget overfor Danmark den 10. Februar 1920. Tyskheden i Nordslesvig, der i 1920 udgjorde 25,000 Stemmer eller 25 pCt., (de fremmede stemmeberettigede medregnet), ved Folketingsvalget 1920 7,505 Stemmer, eller 14,8 pCt., og ved Folketingsvalget 1924 7,724 Stemmer eller 13,6 pCt. af de afgivne Stemmer, har faaet Rammerne i Orden for planmæssigt Arbejde.

Vi gor bedst i fra dansk Side at regne med Forholdene som de er, og gore os Stillingen klar: Vore nationale Modstandere søger at placere det nordslesvigske Spørgsmaals Løsn'ng som en Uret, der er begaaet mod Tyskland. Ved Hjælp af dette og iøvrigt den frembrydende Reaktions Nationalisme ("Ny-Slesvig-holstenismen«) søger de at vække Interesse og Offervillighed først og fremmest i Sydslevig og Holsten, men ogsaa sydfor Elben, hvilket sidste dog endnu kun i ringe Grad er lykkedes.

Overfor dette maa vi Danske være paa vor Post, føre en positiv dansk Polit'k, øge og styrke den hjemlige Danskhed i vort genvundne Land kulturelt og rkonomisk, men ogsaa følge Tyskhedens Arbejde og 
imødegaa det, hvor det $\mathrm{i}$ sin Politiks Tjeneste tager unormale okonomiske Forhold som Valuta-dumping i Handel, tyske Tjenestefolks Anbringelse i de udsatte Sogne eller tyske Kapitalers Opkøb af dansk Jord og Ejendom. Nu er Tiden der, og $\mathrm{n} u$ maa der handles, saasandt Danmark skal fuldføre sin største politiske Opgave i dette Aarhundrede: Nordslesvigs fuldstændige Sammensmeltning med vort gamle Fædreland. 